\title{
Benefit of Moderate Dietary Protein Restriction on Growth in the Young Animal with Experimental Chronic Renal Insufficiency: Importance of Early Growth ${ }^{\mathbf{1}}$
}

\author{
AARON L. FRIEDMAN AND RITA PITYER
}

Department of Pediatrics, University of Wisconsin, Madison, Wisconsin 53792

\begin{abstract}
Using a model of unilateral nephrectomy and contralateral heminephrectomy in weanling rats, we studied the effect of severe $(6 \%)$ and moderate $(14 \%)$ protein restriction on growth and renal function up to 24 wk of age. One-half the normal $(N)$ and chronic renal insufficiency (CRI) rats underwent a cross-over protocol $6 \% \rightarrow$ $14 \%$ and $14 \% \rightarrow 6 \%$ at $10 \mathrm{wk}$ of age to analyze the contribution of early growth on ultimate wt and length. $N$ or CRI fed a $6 \%$ protein diet were the smallest. Animals switched from $6 \% \rightarrow 14 \%$ protein diet did not catch up to their counterparts started on a $14 \%$ protein diet $(N$ or CRI). However, $N$ or CRI animals started on a $14 \%$ protein diet and switched to a $6 \%$ protein diet grew along a curve similar to animals fed a $14 \%$ protein diet. Creatinine clearances for CRI rats were not different among the groups. However, protein excretion was highest in those animals completing the study on a $14 \%$ protein diet. Growth failure caused by severe protein restriction occurred primarily in the early accelerated growth phase (3$10 \mathrm{wk})$. We conclude that moderate protein restriction during the early rapid growth phase maintains growth, whereas severe protein restriction is detrimental to growth. Switching to a more restrictive protein intake after the rapid growth phase did appear to offer more renal protection (lower urinary protein excretion) at the end of $24 \mathrm{wk}$. Severe protein restriction to preserve renal function is a poor strategy for the young rapidly growing individual with chronic renal disease. (Pediatr Res 25: 509-513, 1989)
\end{abstract}

\section{Abbreviations}

$\mathrm{N}$, normal

CRI, chronic renal insufficiency

In recent years the use of protein restriction as a form of therapy in chronic renal failure has received considerable attention (1). Studies in experimental animals have shown that dietary protein restriction can slow the progression of chronic renal disease (2-5). Studies in humans have suggested a retardation in the rate of progression of chronic renal disease in patients eating a low protein diet $(6-10)$. These findings have led to the sugges-

Received August 15, 1988; accepted December 1, 1988.

Reprint requests to Aaron L. Friedman, M.D., University of Wisconsin Hospital and Clinics, Department of Pediatrics, 600 Highland Ave. H4/472, Madison, WI 53792 .

Supported by the National Kidney Foundation of Wisconsin and the Medical School Research Fund of the University of Wisconsin. CA.

Presented in part at the Society for Pediatric Research, April 1986, Anaheim, tion that dietary protein restriction should be included routinely as part of the medical management of chronic renal failure.

What about the use of dietary protein restriction in the growing animal? We have recently described a regimen of moderate protein restriction in an experimental CRI model that preserves renal function and permits normal growth (11). In this study, we demonstrate that the improvement in growth derived from our experimental diet is achieved primarily during the early accelerated growth phase of the young animal.

\section{MATERIALS AND METHODS}

Female Sprague-Dawley rats aged 21-24 d were placed into two experimental groups: $\mathrm{N}$ or CRI. Each experimental group was divided into two diet groups, having either $6 \%$ or $14 \%$ protein. Each of the CRI groups started with 20 to 22 animals. The $\mathrm{N}$ groups each had 10 animals. Diets were prepared by Teklad (Madison, WI) and were isocaloric with identical sodium, potassium, calcium, phosphorus, and vitamin content (by wt). The protein source was casein supplemented with methionine to bring the methionine content to just above the minimum daily requirement (12) (Table 1).

All operative procedures were performed under general anesthesia (Nembutal). CRI was produced by one step uninephrectomy and ligation of approximately $2 / 3$ of the contralateral kidney. Surgery was performed on 21-day-old animals. $\mathrm{N}$ animals underwent a sham procedure (no renal tissue removed or ligated). Mortality in the first $48 \mathrm{~h}$ in CRI animals was $10-15 \%$. All animals were given access immediately to their respective diets.

Studies were confined to $24 \mathrm{wk}$ of age, as the primary goal was to study the effect of protein restriction on early growth. At 10 wk of age $1 / 2$ the animals fed a $6 \%$ protein $\operatorname{diet}(\mathrm{N}$ and $\mathrm{CRI})$ were switched to a $14 \%$ protein diet. At the same age, $1 / 2$ the animals fed a $14 \%$ protein diet were switched to a $6 \%$ protein diet.

Animals were fed ad libitum a fixed preweighed amount of powdered (not pelleted) food. The food was placed in a cup with a center hole in the top. The cup was fixed to the bottom of the cage to prevent spillage. Before the cup was refilled, the amount left was weighed, thereby providing a figure of the amount consumed/d.

At regular intervals, animals were mildly anesthesized with ether for wt and length measurements. Lengths were measured from the nose tip to the tail base. The 18-h urine collections for urinary creatinine and urinary protein excretion were performed on a regular schedule. Urine collections were obtained with animals in metabolic cages overnight and provided water but no food. At the end of the urine collection period, blood samples were obtained from the tail vein for serum creatinine determinations. 
Plasma and urine creatinine were analyzed on a Beckman creatinine autoanalyzer (Beckman Instruments Inc., Brea, CA). Urinary protein was determined by modification of the technique of Lowry et al. (13).

Statistical analysis included determination of the mean plus $\mathrm{SD}$ or SEM. Analysis of differences between groups was performed using ANOVA and ANOVA of the SEM. Determination of $95 \%$ confidence limits was used to measure significance, and, where applicable, standard Student's $t$ test was used. Equations of growth curves were determined by analysis of the curve using Macintosh SE (Cupertino, CA) program.

\section{RESULTS}

Previous studies in our laboratory showed that survival of animals with CRI was improved using a $6 \%$ protein or a $14 \%$ protein diet compared to the standard protein diet $(22-24 \%)$ (11). In the study reported here, all $\mathrm{N}$ animals survived to $24 \mathrm{wk}$. A minimum of eight animals/group survived to $24 \mathrm{wk}$ in the CRI group. Survival was not significantly different between animals fed a $6 \%$ protein or $14 \%$ protein diet. Table 2 shows the creatinine clearance $(\mathrm{mL} / \mathrm{min} / 100 \mathrm{~g}$ body $\mathrm{wt})$ and urinary protein excretion of all four study groups at $24 \mathrm{wk}$ of age. No difference in creatinine clearance or urinary protein excretion could be found between the two $\mathrm{N}$ groups. The CRI animals differed from one another in that animals switched to a $14 \%$ protein diet (from $6 \%$ protein) exhibited more protein excretion at $24 \mathrm{wk}$ of age than animals switched to $6 \%$ protein diet (from a $14 \%$ protein diet). Both CRI groups exhibited higher protein excretion than their normal controls. Creatinine clearance was not different between CRI groups, but both CRI groups had significantly lower creatinine clearances compared to their normal controls.

Figures 1-4 demonstrate the growth data on all the experimental groups. Figures 1 and 2 show wt plotted against age in normal and CRI animals. The plots demonstrate that animals begun on a $6 \%$ protein diet weighed less throughout the period of the study. A switch to a $14 \%$ protein diet at $10 \mathrm{wk}$ of age did

Table 1. Diets (11)

\begin{tabular}{lcc}
\hline & \multicolumn{2}{c}{ Dietary protein } \\
\cline { 2 - 3 } \multicolumn{1}{c}{ Ingredient } & $6 \%$ & $14 \%$ \\
Casein, high protein & 68.886 & 160.735 \\
DL-methionine & 0.545 & 1.273 \\
Cornstarch & 150.0 & 150.0 \\
Sucrose & 597.775 & 517.773 \\
Corn oil & 51.837 & 50.919 \\
Fiber (cellulose) & 67.730 & 56.865 \\
Mineral mix & 35.0 & 35.0 \\
$\mathrm{CaHPO}_{4}$ & 17.719 & 14.894 \\
$\mathrm{CaCO}_{3}$ & 0.508 & 2.541 \\
Vitamin mix & 10.0 & 10.0 \\
\hline
\end{tabular}

not result in catch up to the wt found in animals begun on a $14 \%$ protein diet. CRI or $\mathrm{N}$ animals fed a $14 \%$ protein diet, then switched to $6 \%$ protein, showed no significant difference in wt throughout the study period compared to animals maintained on $14 \%$ protein diet (Figs. 1 and 2). $\mathrm{N}$ animals fed a $6 \%$ protein diet then switched to a $14 \%$ protein diet weighed slightly more than animals maintained on a $6 \%$ protein diet. This difference reached significance only between 17 and 21 wk of age. In CRI animals, animals switched from $6 \%$ to $14 \%$ protein intake weighed slightly more than CRI animals fed only a $6 \%$ protein diet. The difference was significant from 11 to $17 \mathrm{wk}$ of age. After 17 wk of age, no difference between the two groups was seen (Fig. 2). Figures 3 and 4 show length plotted against age in $\mathrm{N}$ and CRI animals. $\mathrm{N}$ and CRI animals fed a $14 \%$ protein diet then switched to $6 \%$ protein showed no significant difference in length throughout the study period (Fig. 3, 4). CRI animals fed a $14 \%$ protein diet and switched to $6 \%$ grew in length along the same curve as CRI animals maintained on a $14 \%$ protein diet (Fig. 4). However CRI animals fed only a $6 \%$ protein diet were significantly shorter than CRI animals switched from $6 \%$ protein to $14 \%$ protein. In fact, CRI animals fed a $6 \%$ protein diet and then switched to a $14 \%$ protein diet grew along a curve identical to normal animals started on a $6 \%$ protein diet (Fig. 4). CRI animals maintained on a $6 \%$ protein diet were shorter than animals in any other experimental group (Figs. 3 and 4).

Growth curves were reanalyzed to construct equations assuming that growth in the first $10 \mathrm{wk}$ of life and after $10 \mathrm{wk}$ of age proceed at different rates. The growth curves were separated at $10 \mathrm{wk}$ and equations were constructed using polynomial analysis. CRI animals started on a $14 \%$ protein diet showed a faster rate

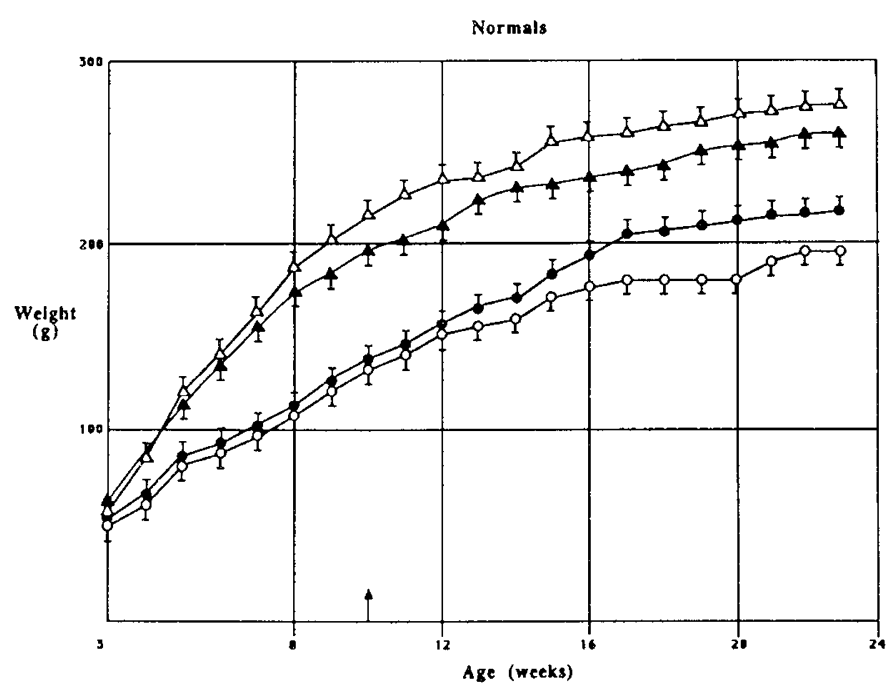

Fig. 1. Growth in wt measured in $g$ plotted against time in wk in normal animals. $\triangle, 14 \%$ protein diet; $\boldsymbol{\Lambda}, 14 \%$ protein diet switched to $6 \%$ protein diet at $10 \mathrm{wk}$ of age; $\mathrm{O}, 6 \%$ protein diet; $\bullet, 6 \%$ protein diet switched to $14 \%$ protein diet at $10 \mathrm{wk}$ of age; $\uparrow$, switch point.

Table 2. Creatinine clearance and urinary protein excretion age 23-24 wk*

\begin{tabular}{cccccc}
\hline & \multicolumn{2}{c}{ Normals } & & CRI \\
\cline { 2 - 3 } \cline { 5 - 6 } & $\begin{array}{c}\text { Creatinine clearance } \\
(\mathrm{mL} / \mathrm{min} / 100 \mathrm{~g})\end{array}$ & $\begin{array}{c}\text { Urinary protein } \\
(\mathrm{mg} \text { protein/mg creatinine })\end{array}$ & & $\begin{array}{c}\text { Creatinine clearance } \\
(\mathrm{mL} / \mathrm{min} / 100 \mathrm{~g})\end{array}$ & $\begin{array}{c}\text { Urinary protein } \\
(\mathrm{mg} \text { protein/mg creatinine })\end{array}$ \\
\hline $6 \% \rightarrow 14 \%$ & $0.57 \pm 0.18$ & $4.45 \pm 2.9$ & & $0.18 \pm 0.031$ & $26.35 \pm 6.53 \dagger, \ddagger$ \\
$14 \% \rightarrow 6 \%$ & $0.49 \pm 0.14$ & $2.14 \pm 0.33$ & & $0.20 \pm 0.021$ & $9.85 \pm 5.49 \dagger, \ddagger$ \\
$6 \%$ & $0.44 \pm 0.15$ & $2.30 \pm 0.09$ & & $0.17 \pm 0.021$ & $10.07 \pm 6.75 \dagger, \S$ \\
$14 \%$ & $0.56 \pm 0.10$ & $3.98 \pm 0.91$ & & $0.21 \pm 0.021$ & $24.56 \pm 6.9 \dagger, \S$ \\
\hline
\end{tabular}

$*$ Values are mean $\pm \mathrm{SD}$.

$\dagger p<0.05$ CRI $v$ s. normal.

$\ddagger p<0.056 \% \rightarrow 14 \%$ vs. $14 \% \rightarrow 6 \%$.

$\S p<0.056 \%$ vs. $14 \%$. 
CRI

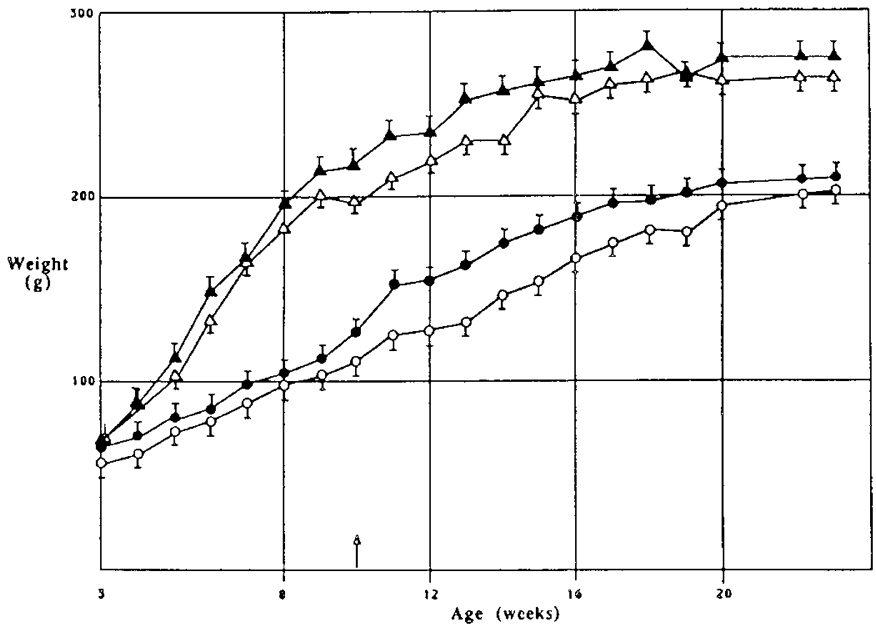

Fig. 2. Growth in wt measured in g, plotted against time in wk in animals with CRI. $\triangle, 14 \%$ protein diet; $\boldsymbol{\Lambda}, 14 \%$ protein diet switched to $6 \%$ protein diet at $10 \mathrm{wk}$ of age; $0,6 \%$ protein diet;, $6 \%$ protein diet switched to $14 \%$ protein diet at $10 \mathrm{wk}$ of age; $\uparrow$, switch point.

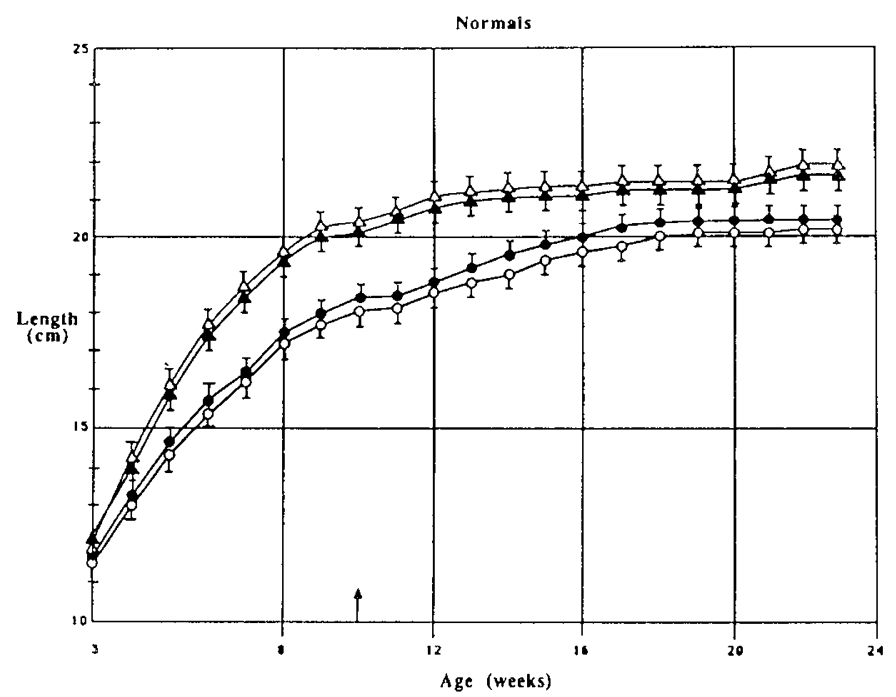

Fig. 3. Growth in length measured in $\mathrm{cm}$ plotted against time in wk in normal animals. $\triangle, 14 \%$ protein diet; $\mathbf{\Lambda}, 14 \%$ protein diet switched to $6 \%$ protein diet at $10 \mathrm{wk}$ of age; $0,6 \%$ protein diet;, $6 \%$ protein diet switched to $14 \%$ protein diet at $10 \mathrm{wk}$ of age; $\uparrow$, switch point.

of growth than animals started on a $6 \%$ protein diet. This difference was seen only in the first $10 \mathrm{wk}$ of age. No difference in growth rate (length or wt) between $14 \%$ protein and $6 \%$ protein diet animals was seen in the 10 - to 24 -wk period. Wt gain was faster in the first $10 \mathrm{wk}$ of age than in the succeeding 14 wk only in animals started on a $14 \%$ diet $(y=20.5 x+65$ at $3-10$ wk versus $y=5.5 x+152$ at $10-24 \mathrm{wk} ; p<0.05)$. In analyzing wt gain in CRI animals started on a $6 \%$ protein diet, the equations demonstrate little alteration in the rate of wt gain between the 3- to 10 -wk period and the 10- to 24 -wk period, regardless of whether the animals were switched to a $14 \%$ protein diet or not. The rate of growth in length was different not only between the $14 \%$ protein diet group and the $6 \%$ protein diet in the first 10 wk of age $(y=1.1 x+12.3 ; 14 \%$ versus $y=0.58 x+$ $12.4 ; 6 \% p<0.05$ ) but also during the 10 - to 24 -wk period in animals switched from $6 \%$ protein to a $14 \%$ protein diet $(y=$ $0.20 x+15.7 ; 6 \%$ to $14 \%$ versus $y=0.18 x+16.5 ; 6 \%$ only; $p<$ $0.025)$. This group ( $6 \%$ protein switched to $14 \%$ protein diet) showed a faster rate of growth in length than animals maintained on $6 \%$ protein diet.

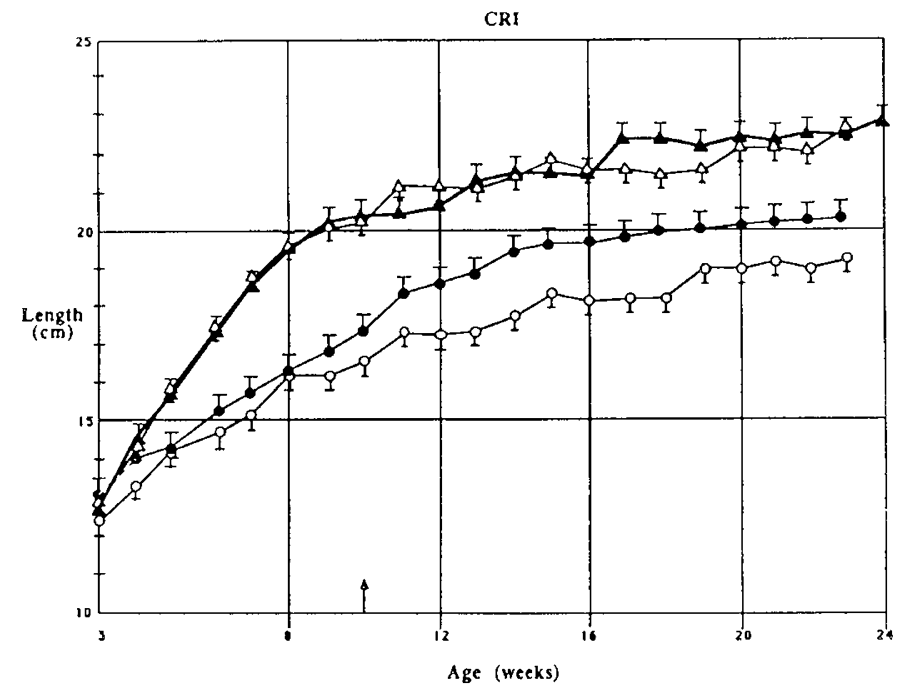

Fig. 4. Growth in length measured in $\mathrm{cm}$ plotted against time in wk in animals with CRI. $\triangle, 14 \%$ protein diet; $\mathbf{\Delta}, 14 \%$ protein diet switched to $6 \%$ protein diet at $10 \mathrm{wk}$ of age; $O, 6 \%$ protein diet;, $6 \%$ protein diet switched to $14 \%$ protein diet at 10 wk of age; $\uparrow$, switch point.

Food intake for $\mathrm{N}$ and CRI started on a $14 \%$ protein diet averaged $10 \mathrm{~g} / \mathrm{d}$ from $3-6 \mathrm{wk}$ of age and rose to an average of $15 \mathrm{~g} / \mathrm{d}$ (range $13-17 \mathrm{~g}$ ) from $17-24$ wk of age. This was true for $\mathrm{N}$ or CRI animals and includes animals switched from $14 \%$ protein to a $6 \%$ protein diet. $\mathrm{N}$ animals started on a $6 \%$ protein diet ate approximately $11 \mathrm{~g}$ of foods/d, which rose to $12 \mathrm{~g} / \mathrm{d}$ after 12 wk of age in the group switched to a $14 \%$ protein diet. CRI animals fed a $6 \%$ protein diet average $10 \mathrm{~g} / \mathrm{d}$ of food intake from 3-11 wk of age, which rose to an average of $12 \mathrm{~g} / \mathrm{d}$ in the group switched to $14 \%$ protein intake. Normal animals maintained on a $6 \%$ protein diet averaged $11 \mathrm{~g}$ of food intake/d from 7-24 wk. CRI animals maintained on $6 \%$ protein diet averaged $10 \mathrm{~g}$ of food intake/d from 7-24 wk of age.

\section{DISCUSSION}

Growth failure in renal insufficiency is a complex, multifactoral problem. At least two important contributing factors to growth failure are: 1) progression of renal disease, and 2) poor nutrition. Considerable evidence exists that in experimental animals with chronic renal failure a protein-restricted diet will delay the progression of renal disease $(6-10)$. We have previously shown that young, experimental animals with chronic renal insufficiency (produced by a surgical reduction of renal mass) can grow normally when fed a moderate protein-restricted diet. In the young animal, when the dietary protein restriction is severe (e.g. 6\% protein diet), as is often utilized in experiments with "adult" animals, growth is significantly reduced as compared to moderate protein restriction (11). In the studies reported here, we examined the importance of maintaining growth early in life especially in renal insufficiency.

Our previous studies suggested that $\mathrm{N}$ and CRI animals exhibited a faster growth rate in the first $10-12$ wk of age than at any time after $12 \mathrm{wk}$ of age. Further, we have found that $\mathrm{N}$ animals fed a $14 \%$ protein diet showed no growth impairment compared to animals fed a standard (22\%) protein diet (11). For these reasons, we chose to use only $14 \%$ and $6 \%$ protein diets and to study the effect of switching diets (from $14 \% \rightarrow 6 \% ; 6 \% \rightarrow 14 \%$ ) at $10 \mathrm{wk}$ of age.

Our data (Figures 1-4) clearly demonstrate that moderate protein "restriction" (14\% compared to the usual protein content of rat food $22-24 \%$ ) will permit normal growth in both $\mathrm{N}$ rats and rats with CRI. However, if more severe protein restriction is used $(6 \%)$, then growth retardation occurs in both $\mathrm{N}$ and CRI animals. Indeed, the growth failure in animals on a $6 \%$ protein 
diet appears to be primarily the result of the diet restriction (Fig. 2 versus Fig. 1, Fig. 4 versus Fig. 3). $\mathrm{N}$ and CRI animals show similar retardation in growth in length, although the length curve in CRI animals started on a $6 \%$ protein diet is even more curtailed than their $\mathrm{N}$ counterparts (Fig. 4 versus Fig. 3). This would suggest a superimposition of the effects of protein restriction plus renal insufficiency on growth in length. Our conclusion that moderate protein restriction will permit normal growth but severe protein restriction will inhibit growth is strengthened by the crossover design of our experiments. Even $\mathrm{N}$ animals fed a $6 \%$ protein diet do not completely catch up in wt or length when fed a $14 \%$ protein diet after the rapid protein diet phase is completed. However, animals ( $\mathrm{N}$ or CRI) fed a $14 \%$ protein diet and switched to $6 \%$ protein diet at the end of (or after) the rapid growth phase displayed growth similar to that of animals maintained on a $14 \%$ diet throughout the study period. Thus, switching to a more severe protein restriction after the rapid growth phase does not have the adverse growth consequences seen when the $6 \%$ protein diet is used very early in the life of the animal.

The use of endogenous creatinine clearance as a measure of glomerular filtration rate has been questioned (14). In general, endogenous creatinine clearance overestimates glomerular filtration rate (as compared to inulin clearance) because of tubular secretion. Because we were interested in repeated measurements over time, we did not use inulin clearance throughout our studies. However, at the time the animals were killed, we did inulin clearances on some of the animals studied $(n=6)$, and we found the inulin clearance to be $10-16 \%$ lower than the creatinine clearance (Friedman AL, Pityer R, unpublished observation). Our purpose in measuring creatinine clearance was to verify that the subtotal nephrectomy did indeed result in CRI. We did not design our studies to assess progression of renal disease. However, we feel endogenous creatinine clearance does show that the animals who underwent nephrectomy developed CRI.

The $14 \% \rightarrow 6 \%$ protein switch also shows the potential to protect renal function. This is seen in Table 2, where, although the creatinine clearance is not different between switch over CRI groups, the protein excretion at the end of the study (23-24 wk) is lower in the group switched from $14 \% \rightarrow 6 \%$ versus the group switched from $6 \% \rightarrow 14 \%$. Animals maintained on a $6 \%$ protein diet for $23 \mathrm{wk}$ excreted $10.07 \pm 6.75 \mathrm{mg}$ protein $/ \mathrm{mg}$ creatinine compared to $9.85 \pm 5.49 \mathrm{mg}$ protein/mg creatinine in the $14 \%$ $\rightarrow 6 \%$ protein group. In the $14 \%$ protein group, urinary protein excretion was $24.56 \mathrm{mg}$ protein $/ \mathrm{mg}$ creatinine compared to 26.35 $\pm 6.53 \mathrm{mg}$ protein $/ \mathrm{mg}$ creatinine excreted on the $6 \% \rightarrow 14 \%$ protein group. These differences in protein excretion between 6 and $14 \%$ protein diet are similar to data we have previously reported (11). Interestingly, in normal animals, no difference in protein excretion could be found between animals fed a $6 \%$ protein diet and those on $14 \%$ protein diet (11). If protein excretion is an early harbinger of change in renal function, then these modest differences may suggest that a $14 \%$ protein diet during the early growth phase to permit more normal growth then switching to a $6 \%$ protein intake to protect renal function after rapid growth has been completed is not only a useful strategy to maintain growth but may protect renal function more so than moderate ( $14 \%$ protein) restriction throughout life. To assess this more fully, studies using a more precise method of renal function analysis are needed.

The data reported here differs from that previously reported by Salusky et al. (16). In that study, Salusky et al. did not find improved survival or growth using a $14 \%$ protein diet. There are a number of possible explanations for this difference. Salusky et al. began their experiments with larger animals. This could have an important effect on the degree of renal insufficiency ultimately created in the animals. Because the kidney size is larger in the larger animal, a more precise amount of kidney removal can be accomplished. But more importantly, in the smaller, younger animal, a greater degree of hypertrophy may develop. This would result in a less severe impairment of renal function and can explain the results we obtained of near normal growth with moderate protein restriction. Another difference between our study and that of Salusky et al. is in the diet used. Our diet was casein based; Salusky et al. used a fish-flour-based diet and was identical (in percentage of diet by wt) in calories, phosphorus, calcium, sodium, chloride, and potassium. The higher protein diet used in the Salusky et al. study also had greater amounts of sodium, calcium, and phosphorus. Thus, animals not only consumed a higher protein diet but also a higher phosphorus diet as well. Both factors have been demonstrated to influence progression of renal disease $(1,2)$.

As a model of chronic renal failure, the rat has some advantages and disadvantages. When one is studying the benefits of an intervention such as a dietary manipulation, the rat model allows the use of large numbers of animals so that statistical significance can be determined. The model of reduced renal mass has been delineated in the rat $(5,15,16)$. However, the rat grows in length and wt throughout its lifetime (17). This means that long term studies looking at growth are not readily applicable to humans. The rat does have a rapid growth phase similar to that of the young child. Studies that focus on growth may be able to use the rat as a model especially if they concentrate on the first 10-12 wk of life. We have done that and further attempted to quantitate growth by curvilinear analysis. By constructing equations to define growth curves, we are demonstrating important differences in growth caused by our dietary interventions. We would suggest that this type of growth analysis will be useful in further experiments aimed at studying dietary or other experimental manipulations on growth in young with chronic renal insufficiency.

In conclusion, animals with chronic renal insufficiency fed a moderate protein-restricted diet (14\%) during first $10 \mathrm{wk}$ of life and then switched to $6 \%$ protein diet for the next $14 \mathrm{wk}$ of life grew along a normal curve similar to that of animals fed a $14 \%$ protein diet for the entire experimental period. Animals fed a $6 \%$ protein diet and then switched to $14 \%$ protein diet after 10 wk of age where smaller than $14 \% \rightarrow 6 \%$ cohorts. These data suggest that severe protein restriction as a strategy to protect renal function should not be used during rapid growth periods but may be useful after rapid growth has been completed.

Acknowledgment. The authors acknowledge the excellent technical support of Wendy Humboldt and the help of Dr. William Ershler.

\section{REFERENCES}

1. Mitch WE 1984 The influence of diet on the progression of renal insufficiency. Annu Rev Med 35:249-264

2. Klahr S, Buerkert J, Purkesson ML 1983 Role of dietary factors in the progression of chronic renal disease. Kidney Int 24:579-587

3. Hostetter TH, Olson JL, Rennke HG, Venkatachalam MA and Brenner BM 1981 Hyperfiltration in remnant nephrons: a potentially adverse response to renal ablation. Am J Physiol 241:F85-F93

4. Brenner BM, Meyer TW, Hostetter TH 1982 Dietary protein intake and the progressive nature of kidney disease: the role of hemodynamically mediated glomerular injury in the pathogenesis of progressive glomerular sclerosis in aging, renal ablation and intrinsic renal disease. N Engl J Med 307:652-659

5. Gretz N, Meisinger E, Strauch M 1986 Experimental models to assess the influence of low protein diets on the progression of chronic renal failure. Contrib Nephrol 53:7-20

6. Alvestrand A, Ahlberg M, Bergstrom J 1983 Retardation of the progression of renal insufficiency in patients treated with low protein diets. Kidney Int 24(suppl 16):268-272

7. Giordano C 1982 Protein restriction in chronic renal failure. Kidney Int 22:401 -408

8. Mitch WE, Walser M, Steinman TI, Hill S, Zeger S and Tongsanga K 1984 The effect of a keto acid-amino acid supplement to a restricted diet on the progression of chronic renal failure. N Engl J Med 31 1:623-629

9. Giovannetti S 1986 Low protein diet in chronic uremia: a historical perspective. Contrib Nephrol 53:1-6

10. Walser M 1981 Conservative treatment of the uremic patient. In: Brenner BM, Rector FC (eds) The Kidney. WB Saunders, Philadelphia, p 2383 
11. Friedman AL, Pityer R 1986 Beneficial effect of moderate protein restriction on growth, renal function and survival in young rat with chronic renal failure. J Nutr 116:2466-2477

12. 1969 Dietary standards for laboratory rats and mice. In: Coates EM, O'Donoghue DN, Doyne PR, Ward RJ (eds) Laboratory Animal Handbook No. 2. London Laboratory Ltd., London

13. Lowry OH, Rosebrough NJ, Farr AL, Randall RJ 1951 Protein measurement with Folin phenol reagent J Biol Chem 193:265-278

14. Mitch WE 1986 Measuring the rate of progression of renal insufficiency in progressive nature of renal disease. In: Mitch WE, Brenner BM, Stein JH (eds) Contemporary Issues in Nephrology. Churchill-Livingstone, New York, p 167

15. Kleinknecht C, Salusky I, Broyer M, Gubler MC 1979 Effect of various protein diets on growth, renal function and survival of uremic rats. Kidney Int 15:534-541

16. Salusky I, Kleinknecht C, Broyer M, Gubler MC 1981 Prolonged renal survival and stunting with protein-deficient diets in experimental uremia. $\mathrm{J} \mathrm{Lab} \mathrm{Clin}$ Med 97:21-30

17. Mehls O, Ritz E 1983 Skeletal growth in experimental uremia. Kidney Int 24(suppl 15):53-62 